\title{
Rural Japanese Students' Sentiments Regarding Japanese Teachers of English
}

\section{Bradford J. Lee}

Fukui University of Technology

Justin L. Bailey

Fukui University of Technology

\section{Reference Data}

Lee, B. J. \& Bailey, J. L. (2021). Rural Japanese students' sentiments regarding Japanese teachers of English. In P. Clements, R. Derrah, \& P. Ferguson (Eds.), Communities of teachers \& learners. JALT. https://doi.org/10.37546/JALTPCP2020-18

English is not a single entity, but rather composed of infinite varieties known collectively as World Englishes. Published research in the Japanese context has overwhelmingly reported students' preference for the Standard American variety, with Japanese English being typically subject to scorn. However, the current study argues that this established narrative has been subject to sampling bias due to homogeneous study locales (mostly in-and-around the Tokyo area) and sample selection (mostly English or Communication majors). Our precursor research on nonEnglish majors residing in rural Japan found no statistical difference between the number of students preferring native English teachers vs. Japanese ones (Lee \& Bailey, 2020). Following this line of research, the current study reports on a qualitative investigation into the sentiments of this underrepresented population. The factors of effective communication, interest in languagelearning strategies, and peace-of-mind were found to be behind the students' positive sentiments towards Japanese Teachers of English.

英語は単一ではなく無限の種類があり、それらは総称して「世界英語(複数形)」と呼ばれている。これまでに発表された日 本に関する研究では、学生が標準的なアメリカン・イングリッシュを好むという報告が圧倒的に多く、ジャパニーズ・イングリッ シュは軽吵の対象とされてきた。かし本論はこのような結果は研究場所(主に東京周辺)とサンプルの選択方法 (主に英語ま たはコミユニケーション專攻の学生)が均一的であるため、サンプリングバイアスの影響を受けていることを指摘した。日本の 地方在住の非英語專攻の学生を対象とした筆者たちによる先行研究では、ネイティブの英語教師を好む学生と日本人教師を
好む学生の間に統計的な違いは見つからなかつた (Lee \& Bailey, 2020)。この一連の調査を受けて、本論では過小評価された 集団の感情に関する定性的調査の結果を報告した。日本人の英語教師に対する学生の好意的な感情の背後には、効果的な コミユニケーション、語学学習戦略への関心、そして安心感という要因があることがわかった。

hen most people talk about English-as-a-Foreign-Language (EFL) education, they rarely make the distinction as to what variety of English they are referring to. Typically, English education and by extension, the English language itself, is discussed as a single entity and without nuance. This author's own past research has fallen into this trap, with titles such as, "A survey of private Japanese university students' attitudes towards English education" (Lee, 2017). However, in the decades since pioneering efforts of early researchers (particularly Kachru, 1965, 1990), the realization that English is not homogenous, but composed of a multitude of variants, has taken hold. A growing body of research giving representation to the dialects and variations of English, known collectively as World Englishes, has raised awareness of the rich diversity of the language even further, and challenges the old-fashioned dichotomous notion of native vs. nonnative speakers (i.e., native-speakerism; Holliday, 2006).

According to Kachru's (1990) model, varieties of English can be visualized as comprising three concentric circles: the inner, outer, and expanding circles. Inner circle countries, such as the United States and United Kingdom, use English as a first (and usually only) language. Outer circle countries, such as India or the Philippines, consist of those countries where English was brought over from Britain during its period of colonial expansion. In such countries, English is one of the official languages, but other languages are widely spoken among the population, particularly in informal settings. Finally, expanding circle countries are those where English is not an official language and is merely studied as a foreign language, such as Japan and China.

In the past, research conducted in the Japanese EFL context has suggested that Japanese students tend to hold the (inner circle) Standard American variety of English in higher regard while largely disdaining the (expanding circle) variety of English spoken 
by Japanese teachers of English (JTE) (e.g., Fukuda, 2010; Harris, 2012; Kavanagh, 2011; Walkinshaw \& Oanh, 2014). This has either led to, or coincided with, the massive EFL industry in Japan largely employing foreign nationals with no teaching certifications or experience; their only qualifications for the job being their status as a native speaker, in other words, from an inner circle country (McConell, 2000). However, our own precursor research recently found novel findings. When we asked, "(h)ow do students value English teachers from various contexts?” (Lee \& Bailey, 2020, p. 244), we found that our students were evenly split in their reported preferences for inner circle or Japanese instructors. While we initially hypothesized that this result was due to the relatively low level of English proficiency of the participants, the current study set out to explicitly investigate the issue asking students why they responded the way they did in our previous study. By this qualitative method, we sought to answer the following research question (RQ):

RQ: What reasons do rural students cite for their dispositions towards English teachers from Japan versus those from inner circle countries?

\section{Review of the Literature}

Japanese EFL Students' Preferences

Several published studies have heretofore surveyed Japanese EFL students' preferences regarding varieties of English, nearly universally finding a preference for inner circle varieties of English, particularly the Standard American variety. This reported preference may be seen as reflective of the widespread and longstanding ideology of nativespeakerism, which frames nonnative speakers as 'others' which can never claim true ownership of the language (Holliday, 2006).

However, each study differs from the current investigation in one or more key aspects, making the current study an entirely unique perspective. It should be noted that the location where a study is conducted has the potential to introduce a significant bias due to the makeup of the local population. For example, the majority of past research has been conducted in, or around, the Tokyo region (e.g., Chiba et al., 1995; Fukuda, 2010; Matsuda, 2003; Matsuura, 2017; Takeshita, 2000). As the largest urban area in the country, Tokyo has the most foreign residents of anywhere in the country with over 581,000 , more than double the number of the next highest prefecture, Aichi (Statistica, 2019). The number of foreign visitors is naturally significantly greater, both in business and tourism sectors. Compared to the foreign population in the prefecture the current study was conducted (Fukui: approximately 15,000: Statistica, 2019), it is clear that the chances of meeting a foreign national and/or having the chance to speak/hear/read
English in a spontaneous, practical situation is much greater for students in Tokyo. This means that while learners in Fukui are clearly in an EFL context, Tokyo-based learners may have more inclinations to view English as a second language, or at least with much more relevance due to its presence in their daily lives.

Another source of bias in past research comes from the area of study of the participant pool. The majority of studies have heretofore investigated students majoring in English (Chiba et al., 1995; Matsuda, 2003; Matsuura, 2017; Miura, 2009; Ohashi, 2012), Communication (Orikasa, 2016), or International Business (Chiba et al., 1995). It can be implied that these students will have several years of multiple English classes per week with multiple instructors (many most likely from foreign countries) and have developed a high level of English proficiency. This is supported by the studies which have provided quantitative proficiency measurements in terms of TOEIC (Test of English for International Communication) scores (e.g., Matsuura, 2017; Matsuura \& Chiba, 2014; Orikasa, 2016) which fall between 350 and 800. As the average TOEIC score in 2017 was 425 among students at technical universities (Nyugaku et al., 2017), the participants of past studies can be classified as generally at-or-above average proficiency, some by a very large margin. However, this focus on English/Communication majors takes a very narrow view and samples only the most motivated students. As Yazawa (2017) notes that confidence and self-efficacy are highly impactful on students' views of their instructors, we argue that more sampling from a wider range of academic majors and proficiency levels is sorely needed.

\section{The Bimodal Paradigm of Japanese EFL}

Ever since the 1980s, the team-teaching model of English education has been implemented in Japan and other East Asian countries (Carley, 2013), the most prominent of which is the 1987 Japan Exchange and Teaching (JET) Programme (http:// jetprogramme.org/en/). Despite Jang et al.'s (2010) explanation that, " (t)he main rationale behind this coordinative approach is that this unique team with different backgrounds and expertise can complement each other to maximize efficiency in the common mission of language teaching" (pg. 249), practitioners have often cited significant hurdles to its application (e.g., infrequency of classes: Carley, 2013; disparate enthusiasm: Friend, 2008; insufficient planning time: Stewart, 2005; differences in educational concepts: Welch, 1998).

Typically, English classes from Kindergarten through $12^{\text {th }}$ grade will involve a nonJapanese Assistant Language Teacher (ALT) making visits to a class under the instruction 
of a Japanese Teacher of English (JTE). As the name implies, the non-Japanese teacher is viewed as an assistant to the JTE and is often used as a supplemental material to provide entertainment (in the form of games or stories from the ALT's home country) and importantly, as a model of so-called correct pronunciation. As a result, Japanese students come to view the two types of English teachers as fulfilling fundamentally different roles (Rebuck, 2005; Sakui, 2004). The JTE, who is able to code-switch to Japanese at will, provides explanations for grammar or other difficult concepts, classroom instructions, and emotional support when necessary (Carson, 2015; Lo \& Macaro, 2012). Meanwhile, the ALT fills a modelling (e.g., listen-and-repeat) or testing role (e.g., listening comprehension, conversation practice). The difference has been shown quantitatively as well, with one analysis of JTE-led oral communication classes finding English spoken only $40 \%$ of the time, compared to $80-100 \%$ when an ALT is present (McConell, 2000).

\section{Participants}

\section{Study Design}

To maintain internal validity, the same participants as the initial study were once again contacted and asked if they would participate in a follow-up study (see Lee \& Bailey, 2020). In total, $N=473$ students from the same private university, located in a rural area of Japan, were involved. The population was a representative sampling of the student body at large as it contained members from every grade level (i.e., ages 18-22), and every academic major offered at the university. The male-to-female ratio was 93:7, equivalent to the gender ratio of the university overall. According to biographical data collected in the initial study, the majority of participants were residents of the rural prefecture where the university was located $(n=291 ; 61.5 \%$, pg. 246$)$ or the surrounding rural areas $(n=$ $104 ; 22.0 \%$, pg. 246).

While individual levels of English proficiency were not assessed at the start of the study, the average TOEIC scores at this university were approximately 346 , placing them behind the national average of 425 for similar universities (Nyugaku et al., 2017, pg. 378). As such, the participants can be classified as being of elementary English listening and reading proficiency. It is also salient that this university does not have an academic major for English-related studies. Participants were therefore non-English majors who only enrolled in two English courses weekly (one focused on listening skills, the other on speaking) to satisfy basic conditions for graduation. Informed consent was obtained from all participants and the project was within institutional review board guidelines for research involving human subjects.
Table 1

Overview of Participants $(\mathrm{N}=473)$

\begin{tabular}{ccccc}
\hline Gender & Grade Level & Age & $\begin{array}{c}\text { Region of } \\
\text { Residence }\end{array}$ & Major $/$ Course \\
\hline $\mathrm{M}=440$ & Freshman $=254$ & 18 yrs. $=1$ & Hokkaido $=2$ & Electrical Engineering $=69$ \\
$\mathrm{~F}=33$ & Sophomore $=177$ & $19 \mathrm{yrs} .=253$ & Tohoku $=0$ & Mechanical Engineering = 123 \\
& Junior $=25$ & 20 yrs. $=177$ & Kanto $=4$ & Civil Engineering $=64$ \\
& Senior $=17$ & 21 yrs. $=25$ & Chubu $=395$ & Nuclear Engineering = 17 \\
& & 22 yrs. $=17$ & Kansai $=56$ & Applied Chemistry = 53 \\
& & Chugoku $=3$ & Information Sciences = 26 \\
& & Shikoku $=3$ & Design $=81$ \\
& & Kyushu $=10$ & Sports \& Health Sciences $=40$ \\
\hline
\end{tabular}

Materials and Methods

Participants were first allowed to review their responses to the initial study through our online system, which had asked them to respond, via a 5-point Likert scale, how they would feel if their English instructors were one of the following: a) a native speaker from an inner circle country (IC), b) a native speaker from an outer circle country (OC), c) a Japanese citizen with excellent English ability (JP), and d) a very good English speaker from an expanding circle country (XC). (Note that while Japan is technically part of the expanding circle, we felt it was necessary to create separate categories of JP and XC to tease apart sentiments which may be biased towards the learners' own language variety and those of other XC variants.)

Although the gold standard for qualitative research is typically face-to-face interviews (e.g., McGrath et al., 2018), written responses were selected for this study due to concerns that students may hesitate to express negative opinions directly to the researchers. The participants were therefore asked to explain, in writing, the scores they had given in the previous session. This was done on the same online system as the initial study, which allowed for anonymization of the responses. Students were allowed to respond in their L1 (Japanese) to allow for the maximum and accurate expression of detail and nuance, which were then transcribed into English by one of the researchers, a holder of the top level (N1) in the Japanese Language Proficiency Test (JPLT). 


\section{JALT2020}

COMMUNITIES OF
TEACHERS \& IEARNERS

\section{Results}

Written responses were first linked with each participant's corresponding Likert data from the initial study. Participants who had responded either 1: That is ideal for me or 2: I would be slightly interested towards the two teacher types of interest (IC, $n=185 ; \mathrm{JP}, n$ $=161$ ) were grouped together as being positive. Likewise, respondents whose responses were 4: I would be slightly concerned, or $5:$ I would be upset (IC, $n=22 ; \mathrm{JP}, n=45$ ), were grouped into a negative category. Data from students who had answered 3: Neutral in the initial study were not included in the analysis (IC, $n=266$; JP, $n=267$ ).

The translated responses (see previous section) were discussed among the two researchers and coded based on the theme of each comment. (Note that comments that touched on multiple themes were coded as one instance of each, thus resulting in a larger $N$.) The themes that emerged from the students' responses are reported below in Table 2.

Table 2

Emergent Themes in Positive and Negative Responses

\begin{tabular}{lll}
\hline & \multicolumn{1}{c}{ IC } & \multicolumn{1}{c}{ JP } \\
\hline Positive Responses & Authenticity $(n=80)$ & Communication $(n=71)$ \\
& Listening $(n=48)$ & Learning Strategies $(n=21)$ \\
& Enjoyment $(n=25)$ & Peace of Mind $(n=42)$ \\
& Intercultural $(n=39)$ & Other $(n=11)$ \\
& Other $(n=14)$ & \\
Negative Responses & Listening $(n=9)$ & Preference $(n=20)$ \\
& Anxiety $(n=5)$ & Alienation $(n=9)$ \\
& Aversion $(n=9)$ & Disinterest $(n=13)$ \\
& & Ability $(n=5)$ \\
\hline
\end{tabular}

Note: $\mathrm{IC}=$ inner circle; JP = Japanese

\section{Native Speakers from an Inner Circle Country}

Positive Responses

As presented in Table 2, the major themes that emerged among positive responses towards English teachers from inner circle countries were authenticity, listening, enjoyment, and intercultural experience, as illustrated in the following excerpts from the data:

- Authenticity

- They can teach me correct pronunciation and practical usage

- They can teach me practical English needed for daily life in the target country

- I am not studying English for a test, I am studying for practical speaking

- Listening

- I feel like I accomplished something when I can understand English spoken by a native speaker

- I want to become accustomed to hearing authentic English

- I feel like my listening ability will greatly improve

- Enjoyment

- Their class atmosphere seems fun

- I want to experience a foreign atmosphere

- I don't have the chance to contact many foreign people except for English class; it is an enjoyable time for me

- Intercultural

- Foreign teachers possess knowledge about foreign countries that I don't have

- Foreign people have a different way of viewing things. I would like to have communication with foreign people

- I want to hear stories about their home countries and things that surprised them about Japan

\section{Negative Responses}

The major themes that emerged among negative responses were listening, anxiety, and aversion. Excerpts from the data illustrating these themes are as follows:

- Listening 


\section{JALT2020}

COMMUNITIES OF
TEACHERS \& IEARNERS

Lee \& Bailey: Rural Japanese Students' Sentiments Regarding Japanese Teachers of English

- Listening is incomprehensible

- Foreign teachers are difficult to understand

- Anxiety

- I fear I won't understand

- I can't communicate at all if the teacher doesn't understand Japanese

- Aversion

- I'm poor at English

- I hate English

\section{Japanese Teachers of English (JTE)}

Positive Responses

With regards to Japanese teachers of English, some themes that were identified were communication, learning strategies, and peace-of-mind, as illustrated in the following excerpts from the data:

- Communication

- I am able to easily ask questions at any time about things I don't understand

- There will be nothing that I won't be able to understand if the teacher is Japanese

- Learning Strategies

- A Japanese teacher will be able to teach me what I need to do in order to be able to speak English in the future

- As someone who knows, a Japanese teacher can teach us the stumbling points in learning English, and how to overcome them

Peace-of-mind

- I am not good at English, so I think a Japanese teacher is kinder for me

- I am used to learning from Japanese teachers since junior high school

- I feel at ease learning from another Japanese person

Negative Responses

The themes that emerged among negative responses were preference, alienation, disinterest, and ability. Note that there were fewer negative responses than positive ones, as the overall impression of JTEs were favorable in the initial study. Excerpts from the data illustrating these themes are as follows:

- Preference

- Even if a Japanese person is good at English, a foreigner is always better

- I can't say why, but I prefer to learn the English of a foreigner

- I hate the English spoken by Japanese teachers

- Alienation

- Some Japanese teachers make fun of students and brag about their level of English ability

- JTEs have too much pride in themselves

- If the teacher is Japanese, I relive bad memories from my junior high school English classes

Disinterest

- I can't feel that JTEs' English is the real thing

- I don't feel like l'd be able to improve my English ability

- JTE classes are boring; ALT classes are more interesting

- Ability

- No matter how good a Japanese gets at English, it can never be perfect. You can't match the level of a person who was born \& raised with English as a mother tongue

- You will always be able to tell the difference in accent of a Japanese person who learnt English in Japan as opposed to the real thing

- I think Japanese teachers can only teach me what's in the textbook

\section{Discussion and Pedagogical Implications}

The varied responses provided by the students suggests that when it comes to preferences regarding IC and JTEs, there is no "one size fits all" and that preferences depend on a myriad of factors such as personal interest, student anxiety, as well as the student's own personal goals for learning the English language. Results indicated that teachers from IC countries appeal more to students by providing authenticity to the classroom environment, as well as being able to provide intercultural insights and enjoyment to the learning experience. JTEs, on the other hand, were highly valued for 
their ability to communicate, explain, teach effective learning strategies, and provide emotional support.

With regards to the negative comments about IC teachers, it appears that many are related to students' anxieties (e.g., fear of not being understood, feeling insecure about their own proficiency in the English language), reflecting the effects of language proficiency as a previously unidentified independent variable. It would appear that part of the reason why many of the students in this sample responded differently from those of past research (which showed a strong preference for IC teachers) is due to self-confidence in their communicative abilities. As previously mentioned, the sample consisted of non-English majors with lower TOIEC scores than the national average. In addition, the majority of participants came from Fukui, a rural prefecture with few foreign residents from IC countries, placing them in an EFL context. As such, the participants are in a context where English courses are not aimed at developing communicative competence, but rather for the purposes of test-taking and/or job placement.

From a pedagogical perspective, we argue that the sample population in this study, while heretofore massively underrepresented in the current literature, are actually more representative of the average Japanese language learner than those of previous studies. Indeed, JTEs appear to have an incredibly important role to play in Japan's English education system, mainly supporting the development of younger, lower-level learners, or those with high degrees of anxiety from a technical (e.g., vocabulary, grammar) or advisory (e.g., language-learning strategies) capacity. However, IC teachers still appear to be the most desirable in terms of challenging one's abilities (to listen or communicate effectively) and gaining intercultural exposure/understanding.

\section{Conclusion}

The current study sought to expand on precursor research into Japanese students' sentiments regarding their English teacher. Our study, which focused on rural students from non-English majors, suggested that in this context, JTEs were valued just as highly as IC teachers. This is a novel finding in Japanese EFL research which may be a direct consequence of differences in sampling methodology. Although methods and instruments differ from other works in this field which limit direct comparison, this study hopes to raise awareness that wider representation is needed to counteract the effects of sampling bias in Japanese EFL research.

\section{Limitations and Implications for Future Research}

As stated in the Materials and Methods section, responses were elicited in a written format for participants to maintain anonymity and to give sufficient time for thinking However, this precluded the ability for the researchers to ask for clarification or to ask follow-up questions which may have further elicited rich data. Due to the sensitive nature of the topic, it is debatable as to which method would be more effective, as some participants may be reticent to give such strong responses as, "I hate the English spoken by Japanese teachers" if the interviewer were a JTE, and vice versa. One possible method may be to recruit an experienced interviewer who is not connected with English education for future studies.

The age group under investigation is another independent variable that is believed to be highly impactful on the results. In fact, while the current study investigated collegelevel learners, some respondents referenced their experiences in the past with JTEs and ALTs in junior and senior high school as informing their opinions. Consequently, investigating other age groups such as kindergarten or elementary school children would allow for garnering reactions before they have gone through the notoriously test-based curriculum of secondary school. Likewise, researching adults and businesspeople who are either involved with international dealings, or who are learning English purely for enjoyment, could result in different findings. Overall, it is hoped that this study elucidates that similarly to how English is composed of infinite varieties depending on the speakers' region, the landscape of language learners is similarly diverse, depending on each person's goals, background, and context.

\section{Bio Data}

Bradford J. Lee (ORCID ID 0000-0001-9833-5631) holds an Ed.D. in TESOL from Anaheim University, a M.A. in Applied Linguistics from the University of Newcastle, and a B.A. in Linguistics from the University of Hawaii. He is currently an Associate Professor in the Organization for Fundamental Education at Fukui University of Technology. His main research areas include phonology/pronunciation instruction, noticing/perceptionbased instruction, and smartphone-based writing. <bradford-lee@fukui-ut.ac.jp>

Justin L. Bailey (ORCID ID 0000-0003-1983-821X) holds a M.A. in Applied Linguistics from the University of Leicester and a B.Sc. in Psychology from Aston University. He is currently working as an Assistant Professor in the Organization for Fundamental Education at Fukui University of Technology. His research areas include test washback and English as a world language. <j-bailey@fukui-ut.ac.jp> 
JALT2020

TEACHERS \& LEARNERS

Lee \& Bailey: Rural Japanese Students' Sentiments Regarding Japanese Teachers of English

\section{References}

Carley, H. F. (2013). Team teaching styles utilized in Japan: Do they really work? Journal of International Education Research, 9(3), 247-252. https://doi.org/10.19030/jier.v9i3.7882

Carson, E. (2015). Introducing a new scale: Student preferences for institutional language (SPIL). Japanese Association of College English Teachers: Chugoku-Shikoku Chapter Regional Bulletin, 12, 19-36.

Chiba, R., Matsuura, H., \& Yamamoto, A. (1995). Japanese attitudes towards English accents. World Englishes, 14(1), 77-86. https://doi.org/10.1111/j.1467-971X.1995.tb00341.x

Friend, M. (2008). Co-teaching: A simple solution that isn't simple after all. Journal of Curriculum and Instruction, 2(2), 9-19. https://doi.org/10.3776/joci.2008.v2n2p9-19

Fukuda, T. (2010). Japanese students' perception of American English. In A. M. Stoke (Ed.), JALT2009 Conference Proceedings. Tokyo: JALT.

Harris, J. (2012). World Englishes and English as a lingua franca: Application in the English classroom in Japan. Forum of Higher Education Research, 2(2012), 25-34.

Holliday, A. (2006). Native-speakerism. ELT Journal, 60(4), 385-387. https://doi.org/10.1093/elt/ ccl030

Jang, S. H., Nguyen, B. H., \& Yang, Y. (2010). Enhancing pedagogical roles of ESL/EFL native and non-native teachers through team teaching: How to make this 'international partnership' successful. The International Journal of Teaching, 17(9), 249-258. https://doi.org/10.18848/14479494/CGP/v17i09/47253

Kachru, B. B. (1965). The Indianness in Indian English. WORD, 21(3), 391-410. https://doi.org/10.10 80/00437956.1965.11435436

Kachru, B. B. (1990). World Englishes and applied linguistics. World Englishes, 9(1), 3-20. https:// doi.org/10.1111/j.1467-971X.1990.tb00683.x

Kavanagh, B. (2011). The ideal English teacher and the commodity of the native speaker. The English Connection, 15(1), 1-9.

Lee, B. (2017). A survey of private Japanese university students' attitudes towards English education. Memoirs of Fukui University of Technology, 47, 304-310. http://hdl.handle. net/10461/28630

Lee, B. J., \& Bailey, J. L. (2020). Japanese tertiary-level students' cognition of World Englishes. Memoirs of Fukui University of Technology, 50, 243-253. http://hdl.handle. net/10461/29339

Lo, Y. Y., \& Macaro, E. (2012). The medium of instruction and classroom interaction: Evidence from Hong Kong secondary schools. International Journal of Bilingual Education and Bilingualism, 15(1), 29-52. https://doi.org/10.1080/13670050.2011.588307

Matsuda, A. (2003). The ownership of English in Japanese secondary schools. World Englishes, 22(4), 483-496. https://doi.org/10.1111/j.1467-971X.2003.00314.x
Matsuura, H. (2017). Listening to unfamiliar English accents: Japanese EFL learners' perception and comprehension. Journal of Commerce, Economics and Economic History, 86(1), 1-11.

Matsuura, H., \& Chiba, R. (2014). Students' attitudes towards unfamiliar English accents and their L1-speaking backgrounds. 商学論集, 82(4), 3-13.

McConell, D. L. (2000). Importing Diversity: Inside Japan's JET Program. University of California Press: London.

McGrath, C., \& Palmgren, P. J., \& Liljedahl, M. (2018). Twelve tips for conducting qualitative research interviews. Medical Teacher, 41(9), 1002-1006. https://doi.org/10.1080/014215 9X.2018.1497149

Miura, S. (2009). University students' attitudes towards varieties of English. The Tsuru University Review, 70, 33-48

Nyugaku, N., Koyama, M., Lee, B., \& Thomson, S. (2017). On the application of communicative approach in English education at Fukui University of Technology. (Japanese language). Memoir of Fukui University of Technology, 47, 373-381. http://hdl.handle.net/10461/28638

Ohashi, L. (2012). World Englishes in the Japanese context: An exploration of Japanese university students' perspectives. 淑徳大学国際経営・文化研究, 17(1), 41-48.

Orikasa, M. (2016). The intelligibility of varieties of English in Japan. World Englishes, 35(3), 355371. https://doi.org/10.1111/weng.12209

Rebuck, M. (2005). The use of Japanese by native English-speaking teachers: The students' perspective. Journal of Humanities and Social Sciences, 18, 135-158.

Sakui, K. (2004). Wearing two pairs of shoes: Language teaching in Japan. ELT Journal, 58(2), 155163. https://doi.org/10.1093/elt/58.2.155

Statistica Research Department. (December 2019). Number of registered foreign residents living in Japan as of June 2019, by prefecture (in thousands). Statistica.com. https://www.statista.com/ statistics/687916/japan-foreign-residents-number-by-prefecture/\#: :text=As\%20of\%20June\%20 2019\%2C\%20more,residents\%20lived\%20in\%20Tokyo\%20Prefecture

Stewart, T. (2005). Interdisciplinary team teaching as a model for teacher development. TESL-EJ Top, 9(2), 45-58.

Takeshita, Y. (2000). Japanese English as a variety of Asian Englishes and Japanese students of English. Intercultural Communication Studies, 10(1), 1-8.

Walkinshaw, I. \& Oanh, D. H. (2014). Native and non-native English language teachers: Student perceptions in Vietnam and Japan. SAGE Open, 4(2). https://doi. org/10.1177\%2F215824401453445

Welch, M. (1998). Collaboration: Staying on the bandwagon. Journal of Teacher Education, 49(1), 26-37. https://doi.org/10.1177\%2F0022487198049001004

Yazawa, O. (2017). Students' perception of native English-speaking teachers and Japanese teachers of English: The effect on students' self-efficacy and emotional state. Eruditi, 1(3), 61-72. 